\title{
2 HumAN FLOURISHING, CHURCH LEADERSHIP AND LEGAL DISPUTES IN NIGERIAN CHURCHES
}

\section{Idowu A. Akinloye ${ }^{1}$}

\section{INTRODUCTION}

Legal disputes involving Christian church leadership that have to be adjudicated by the civil courts have been on the increase in Nigeria in recent years. Although no church tradition is immune to such disputes, a survey of the reported civil cases suggests the disputes are prominent amongst charismatic, Pentecostal and African Independent Churches. For example, churches like Foursquare Gospel Church, ${ }^{2}$ Christ Apostolic Church, ${ }^{3}$ Assemblies of God Church, ${ }^{4}$ Cherubim and Seraphim Church, ${ }^{5}$ the Celestial Church of Christ, ${ }^{6}$ amongst others, have been at the centre of litigation regarding their leadership. These disputes are of concern, because they impact the reputation of churches. They are also beginning to have implications for the churches' sustainability in the promotion of human flourishing. Against this backdrop, this chapter, using literature and analyses of judicial decisions, examines the effects of legal disputes involving church leadership on human flourishing within the Nigerian context. The chapter identifies a vacuum in the internal governance of churches as one of the major factors leading to the disputes. It advocates the need for churches to be more conscious of the legal risks inherent in their internal governance activities, particularly with regard to their leadership, and to develop appropriate risk policies to reduce their exposure to likely disputes.

The chapter is structured as follows. The next section gives a clarification of the key concepts used. It then examines the activities of some Nigerian churches that make the citizens flourish. Thereafter, the chapter briefly examines leadership disputes involving Celestial Church of Christ and Christ Apostolic Church, as case examples. Drawing inferences from these case examples and other relevant instances, the chapter evaluates how church disputes impact the well-being of church members and non-members. Thereafter, it articulates some internal and external risk policies

1 Doctoral candidate, Faculty of Law, Rhodes University, Grahamstown, South Africa.

2 The Registered Trustees of Four Square Gospel Church in Nigeria v Rev. Isaac Adeyemi (Unreported, Suit No. NICN/LA/599/2014).

3 Pastor Akintola and Others $v$ Incorporated Trustees of Christ Apostolic Church and Others (Unreported, Suit No. CA/L/536/11); Asonye v Registered Trustees of Christ Apostolic Church (1995) 2 NWLR (Pt 379) 623 (CA).

4 Rev. Paul Emeka v Rev. Chidi Okoroafor and Others (2017) LPELR-41738 SC; Rev. Nicholas Anyanwu $v$ Rev. Chidi Okoroafor and Others (Unreported, Suit No. FCT/HC/CV/1889/2014).

5 Segun Ajayi $v$ The Registered Trustees of Ina Iwa Mimo Cherubim and Seraphim Church (1998) 7 NWLR (Pt. 556) 156; Eternal Sacred Order of the Cherubim and Seraphim Church $v$ Otubu (1985) HCNLR 943.

6 Owodunni v Registered Trustees of Celestial Church of Christ (2000)10 NWLR (Pt. 675) 315. 
that churches may adopt and embed in their governance mechanisms to prevent and manage their exposure to likely disputes. The chapter concludes by arguing that, although churches may not be completely insulated from disputes because it is in the nature of people to differ and manifest their differences, having effective governance mechanisms in place will play a role in reducing churches' susceptibility to the risks of disputes that ultimately affect human flourishing.

\section{CONCEPTUALISATION OF TERMS}

Perhaps it is best to commence with a conceptual clarification of the terms used. The word "church" lacks a precise definition. However, in Segun Ajayi v The Registered Trustees of Ona Iwa Mimo Cherubim and Seraphim Church, ${ }^{7}$ the court stated: "A church in its true definition is the body of Christ. One person cannot constitute the body of Christ; it connotes a congregation, an assembly of people. An individual cannot own a church." 8 This definition describes a church from two perspectives. First, it depicts a church as an organism, which is the entirety of all Christian faithful. Secondly, it sees a church as a local congregation or religious community of a particular sect of a Christian denomination. The focus of this chapter falls specifically on the second usage of the word. In this context, therefore, a church refers to a particular Christian congregation whose primary purpose is to conduct worship and proclaim the gospel of Jesus Christ. This includes the mainline, ${ }^{9}$ evangelical and charismatic, ${ }^{10}$ and African Independent Churches, such as the Church of Aladura.

"Church dispute" in this chapter refers to a conflict or disagreement between members of a church involving its leadership, which result in a lawsuit before a secular law court. "Flourishing" on the other hand, is from the Greek word eudaimonia, translated as happiness or welfare. Thus, "human flourishing" can literally be said to mean human well-being or happiness. From the available literature, however, the conceptions of the scope of the phrase appear numerous and the views on the concept also differ. ${ }^{11}$ Notwithstanding the diversity of its scope, the general consensus is that human flourishing involves acts that seek the good and well-being of both the individuals and society. This chapter adopts the definition of human flourishing articulated by Tyler VanderWeele, a professor of

$7 \quad$ (1998) 7 NWLR (Pt. 556) 156.

8 The decision in Segun Ajayi appears to follow the definition given by FitzGibbon LJ in MacLaughlin v Campbell (1906) 1 Ir R 877 where he stated that "church has two distinct meanings: (i) it may mean the aggregate of the individual members of the 'church' or (ii) it may mean the quasi-corporate institution which carries on the religious work of the denomination whose name it bears".

9 Example of mainline churches include Anglican, Methodist and Catholic churches.

10 Example of charismatic Pentecostal churches include Winners Chapel, Redeemed Christian Church of God.

11 Alexander GS. 2018. Property and Human Flourishing. Oxford: Oxford University Press, 4; Kleinig J and Evans NG. 2013. "Human Flourishing, Human Dignity, and Human Rights", Law and Philosophy 32:540-548. 
public health. VanderWeele posits that human flourishing consists of five broad domains of human welfare: "mental and physical health", "happiness and life satisfaction", "meaning and purpose", "character and virtue" and "close social relationships". ${ }^{12}$

\section{CHURCHES AND THE PROMOTION OF HUMAN FLOURISHING}

Notwithstanding the argument of critics such as Douglas Anele, a Nigerian public commentator, that religion is outdated and an impediment to the progress of science and harmful to individuals as well as to the society, ${ }^{13}$ research findings have shown that religion contributes to the welfare of people. For instance, it is reported that attendance and participation in a religious community, such as church activities, are closely associated with the various indicia of human flourishing, such as greater longevity, ${ }^{14}$ enhanced happiness and life satisfaction, ${ }^{15}$ greater meaning in life, ${ }^{16}$ lower incidence of depression ${ }^{17}$ and suicide, ${ }^{18}$ better survival from sickness, ${ }^{19}$ amongst others. Although most of these findings were made outside Nigeria, it is no exaggeration to posit that similar and possibly more positive results could be made in Nigeria. Nigerian churches, through their activities, have closed developmental gaps, elevating humankind through capacity-building, and reducing government expenses by rendering social services that are qualitative and economic benefits to the state and the public. For example, churches have been an avenue for reducing the rate of unemployment in Nigeria. Many churches have upwards of twenty employees. The Living Faith Church (also known as the

12 VanderWeele TJ. 2017. "On the Promotion of Human Flourishing", Proceedings of the National Academy of Sciences 114(31):8148.

13 Anele G. 2014. "How Religion Underdeveloped Nigeria (1-4)”, Vanguard, 5 January. See also Oguntokun OO. 2017. "Culture and Religion as Impediments to the Elimination of Violence against Women and Girls Child in Nigeria", Baze University Law Journal 235-253.

14 Hummer RA, Rogers RG, Nam CB and Ellison CG. 1999. "Religious Involvement and U.S. Adult Mortality", Demography 36:273-285; Musick MA, House JS and Williams DR. 2004. "Attendance at Religious Services and Mortality in a National Sample", Journal of Health and Social Behaviour 45:198-213.

15 Lim C and Putnam RD. 2010. "Religion, Social Networks, and Life Satisfaction", American Sociological Review 75:914-933.

16 Krause N and Hayward RD. 2012. "Religion, Meaning in Life, and Change in Physical Functioning During Late Adulthood", Journal of Adult Development 19:158-169.

17 Balbuena L, Baetz M and Bowen R. 2013. "Religious Attendance, Spirituality, and Major Depression in Canada: A 14-Year Follow-up Study", Canadian Journal Psychiatry 58:225-232.

18 VanderWeele TJ, Li S, Tsai AC and Kawachi I. 2016. “Association between Religious Service Attendance and Lower Suicide Rates among US Women", JAMA Psychiatry 73:845-851.

19 VanderWeele, "On the Promotion of Human Flourishing", 8152. See also Koenig HG, King DE and Carson VB. 2012. Handbook of Religion and Health. Second Edition. Oxford: Oxford University Press. 
Winners' Chapel) is reported to employ more than 18,000 personnel. ${ }^{20}$ Churches also contribute to the educational development of the country. Most churches now operate schools from childcare to university level. ${ }^{21}$ Today in Nigeria, no fewer than thirty universities are run privately by churches. ${ }^{22}$ These church-owned universities are complementing the efforts of the government in providing admission to those seeking a university education.

Churches have recorded great achievements through service deliveries in the area of healthcare. ${ }^{23}$ They also frequently provide the impetus for the country's economic and infrastructural development. Recently, in 2017, the Deeper Life Bible Church built and donated a bridge, traffic lights, and a 600-capacity, multilevel public car park to the Lagos State Government in Nigeria. ${ }^{24}$ Some of the church programmes also play a role in the development of religious tourism. ${ }^{25}$ Churches can also be argued to foster close social relationships and unity amongst Nigerians. As far back as 1972, a Nigerian-based sociologist and scholar, PC Lloyd, pinpointed the pluralistic nature of the Nigerian nation as a potential factor fuelling hostility amongst various ethnic groups. ${ }^{26}$ Lloyd's assertion may also have prompted the government to take political and statutory initiatives to promote national unity and social cohesion amongst Nigerians. Such initiatives included the establishment of

20 Cocks T. 2014. "Mega-Churches: The Hidden Pillar of Nigeria's Economy", Mail and Guardian, 12 October.

21 Omotoye RW. 2010. "The Role of Christian Missionaries in the Development of Western Education in Nigeria", in Abiri JO and Jekayinfa AA (eds). Perspective on the History of Education in Nigeria. Ilorin: Bamitex Printing, 72-86.

22 National University Commission. Online at: http://nuc.edu.ng/nigerian-univerisities/ private-univeristies [Accessed 31 March 2018]; Je'adayibe GD. 2016. "Religion and National Transformation", in Quadri YA, Omotoye RW and Adebayo RI (eds). Religion in Contemporary Nigeria. London: Adonis \& Abbey Publisher, 24.

23 See Olarinoye G. 2018. "Church Donates Five Million Naira Modern Equipment to Osun State Government", Vanguard, 11 May.

24 Adesulu D. 2018. "Ambode Commissions Bridge, Car Park Built by Deeper Life Church", Vanguard, 27 February; Sam Adeyemi, the senior pastor of Daystar Christian Centre, a charismatic church located in Lagos, which is widely credited for regularly donating buildings and educational materials to public schools and medical equipment to the government and public, says, showing the love of Jesus in practical terms and the need to meet the need of the society are the motivation of its church's community projects as against gaining any preferential treatment from the state. For details, see Oguntola S. 2016. "Daystar Christian Centre: Undying Passion for Humanity", The Nation, 3 April; Daystar Christian Centre. "Community Impact". Online at: https://daystarng.org/communityimpact [Accessed 21 January 2019].

25 Adelegan F. 2013. Nigeria's Leading Lights of the Gospel: Revolutionaries in Worldwide Christianity. Bloomington: West Bow Press, 57; Ukah A. 2003. "Advertising God: Nigerian Christian Video-Films and the Power of Consumer Culture", Journal of Religion in Africa 33(2):203-204.

26 Lloyd PC. 1972. "The Ethnic Background to the Nigerian Civil War", in Panter-Brick SK (ed). Nigerian Politics and Military Rule: Prelude to Civil War. London: Institute of Commonwealth Studies, 1-13. 
the Federal Character Commission ${ }^{27}$ and National Youth Services Corps Scheme, ${ }^{28}$ in addition to the insertion of the national integration policy in Section 15 of the Constitution. However, scholars such as Francis Oyebade ${ }^{29}$ and Chukwuemeka Okafor, ${ }^{30}$ and other public commentators, such as Joseph Odey ${ }^{31}$ have argued that these government initiatives have proved ineffective. ${ }^{32}$ However, church programmes and activities appear to be more effective in bringing Nigerians from different cultural backgrounds together than the aforementioned initiatives. For example, over a million Nigerians from almost every tribe in the country converge monthly and annually for church services organised by the Redeemed Christian Church of God and other church denominations. ${ }^{33}$ Through the above examples, it can be argued that churches have contributed towards the well-being of Nigerians.

\section{CHURCH DISPUTES}

In spite of the above-noted contributions of churches, there is a rise in the number of legal disputes in Nigeria involving church leadership. All of the churches involved in these disputes may not be effectively examined in this chapter, but two churches, the Celestial Church of Christ and the Christ Apostolic Church, can serve as good case studies. These two churches were selected because they fall within the Pentecostal and African Independent Churches, in which leadership disputes appears to be prevalent. Suffice to mention at the outset that the examination of the disputes in these churches is not to determine the rightness or otherwise of the courts' decisions regarding their lawsuits. Rather, it is primarily to highlight how these disputes affect the flourishing of church congregants and non-congregants.

27 See the Constitution of the Federal Republic of Nigeria, 1999, secs 14(3) and 153(1)(c); Federal Character Commission (Establishment, etc.) Act 34 of 1996, secs 4 and 5. The Federal Character Commission was established to promote proportional sharing of all bureaucratic, economic, media and political posts at all levels of government to all the representative geographical zones in Nigeria.

28 The National Youth Service Corps (NYSC) was established in terms of the National Youth Service Corps Act 51 of 1993, secs 1(2)(a) and (b), which provide that the aim of establishing the scheme was to give encouragement and development of common ties amongst the Nigerian youths and to promote national unity.

29 Oyebade FO. 2016. "National Integration Problem in Nigeria: Exploring a Languagebased Solution", in Ndimele OM, Yuka LC and Ilori JF (eds). Issues in Contemporary African Linguistics: A Festschrift for Oladele Awobuluyi. Port Harcourt: MJ Orbit Communications, 9.

30 Okafor C and Ani JK. 2014. "The National Youth Service Corps Programme and Growing Security Threat in Nigeria", Africa's Public Service Delivery \& Performance Review 2(2):150-151. The authors identify national insecurity as the major bane to the realisation of the goals of the NYSC scheme.

31 Odey JO. 2016. "Is NYSC Still Relevant", The Nation, 28 July. Odey identifies poor funding, bureaucracy and corruption as part of the reason for the ineffectiveness of the NYSC scheme.

32 Oyebade, "National Integration Problem in Nigeria: Exploring a Language-based Solution", 9.

33 Je'adayibe, "Religion and National Transformation", 19. 


\section{Celestial Church of Christ (CCC)}

The CCC is an African Independent Church established by Rev Samuel Oshoffa in 1942. The church became popular and grew very fast in Nigeria, and it spread to various countries, particularly in the 1970s. However, since the death of the founder in 1985, the church has been enmeshed in protracted leadership crises that have led to its polarisation. Reverends Emmanuel Oshoffa, Paul Maforikan, Godwin Shonekan, Josiah Owodunni, Steven Orovboni, MO Akinsoji and Benoit Adeogun, at various times, all claimed the spiritual headship of the church and operating from their individual domains and factions. ${ }^{34}$ The church crises reportedly led to physical protests, assault and violence. In fact, rival claimants were allegedly using "charms" to fight and suppress one another..$^{35}$ Evangelist Edward Oladokun, a leader in the church, further alleged that the contending leaders of the church were falsifying vital church documents to pave way for their ambitions. ${ }^{36}$

The leadership crisis in this church resulted in no fewer than four lawsuits ${ }^{37}$ to determine the rightful successor of the founder, as well as who was legitimately entitled to take possession and manage the church finance and property. In the first suit, that is, Owodunni v Registered Trustees of the Celestial Church of Christ, ${ }^{38}$ the claimant challenged the emergence of Rev Alexander Bada as the founder's immediate successor. The Nigerian Supreme Court observed in its judgment that the church leadership dispute had disintegrated relations between the church congregants and leaders. It also noted that members belonging to different leadership factions used violence and police to oppress one another. ${ }^{39}$ In his lead judgment, Justice Ogundare said: "This matter commenced in October 1987, that is, almost 13 years ago. It must have undoubtedly polarised the Celestial Church of Christ and dispirited its members." ${ }^{40}$ Ogundare went further:

On the 24th January 1988, when the plaintiffs ... sought to attend the said Church for the purposes of worshipping therein, the defendants by Counter-claim with a show of force both by policemen and many members of the said church prevented them from doing so ... The relationship between the Board of Trustees and Parochial Committee represented by the plaintiff, 2nd and 3rd defendants is already strained. In my way of thinking, to make

34 Adeseri L. 2015. "Celestial Church Leadership Crisis: Obasanjo Plays Peace Maker", Vanguard, 20 August.

35 Awojobi PO. n.d. "Leadership Conflict in the Nigerian Church". Online at: http://www. biblicaltheology.com/Research/AwojobiPO01.pdf

Busari A. 2010. "Late Bada, Owodunni Accused of Forgery", PM News, 11 September.

See Registered Trustees of the Celestial Church of Christ $v$ Godwin Shonekan (Unreported, Suit No. HCL /07/2006). The case of Corporate Affairs Commission $v$ The Registered Trustees of the Celestial Church of Christ (2009) 11 NWLR (PT 1151) 40; Celestial Church of Christ, Edward Street Parish (A Charity) v Lawson [2017] EWHC 97 (Ch).

(2000)10 NWLR (Pt. 675) 315.

See also Latona O. 2010. "Group Petitions Inspector General of Police over Celestial Church of Christ Pastors", Vanguard, 18 April.

Owodunni, 344 (emphasis added). 
a declaration that the defendants are entitled to the possession, management and control of the premises and property of the Church building ... would further tear apart the Church from the middle down. ${ }^{41}$

One important point that the Court identified as the cause of the disputes was the inadequacy of the church's constitution to provide for effective processes for the emergence of the successor to the founder in the failure of the founder to name his successor before his death. This is because the constitution of the church provides that the founder will name his successor. ${ }^{42}$ Unfortunately, the founder died from an accident before naming his successor.

\section{Christ Apostolic Church (CAC)}

The CAC is an African Independent and Pentecostal church established in $1928 .{ }^{43}$ Christopher Oshun, a professor of church history who is also a pastor in the church, says the leadership crisis in the church started almost from its inception. ${ }^{44}$ It appears none of the crises in earlier times resulted in litigation. However, since the early 1990s, the church has been embroiled in serious leadership crises resulting in several lawsuits. The crises have polarised the church into two main leadership factions the General Executive Council and the Supreme Executive Council. ${ }^{45}$ In Pastor John Obafemi $v$ Pastor Elijah Oluseye, ${ }^{46}$ one of the suits that emerged from the disputes, the plaintiff's faction challenged in the Federal High Court the emergence of pastor Abraham Akinosun of the General Executive Council as the president of the church. Another major issue raised in the suit was determination of which faction was the authentic authority of the church. This suit is now on appeal before the Court of Appeal, Lagos. What appears to be the messiest of all the cases is State $v$ Pastor Elijah Oluseye and Others. ${ }^{47}$ In this criminal suit, the ex-president of the church, pastor Elijah Oluseye, was alleged to have handed over a forged certificate of incorporation of the church trustees to his successor, pastor Abraham Akinosun. Consequently, the state brought a nine-count charge centred on allegations of forgery of minutes of meetings, conspiracy, fraudulently obtaining a certificate of incorporation of church trustees, amongst others, against Pastor Oluseye and other church leaders.

41 Owodunni, 347 (emphasis added).

42 See, the Constitution of Celestial Church of Christ (Nigeria Diocese), 1980, sec 111.

43 Adeoti EO. 2015. "Origin, Nature and Trajectory of the Leadership Tussle in the Christ Apostolic Church, Nigeria: 1989-2010", Review of Public Administration and Management 3(7):22.

44 Oshun CO. 1989. "Proliferation of Churches in Nigeria: A Consideration of the Christ Apostolic Church", in Adewale SA (ed). Proliferation of Churches in Nigeria. Ibadan: N.A.C.S. Publishers, 13-14.

Alokan OAP, Alabi DO and Babalola SF. 2011. "Critical Analyses of Church Politics and Crises within the Indigenous Christianity in Nigeria", American Journal of Social and Management Sciences 2(4):364; Alokan A. 2000. Cradle and Beyond. Ile-Ife: Timade Ventures, 201. 
The messy news of these lawsuits frequently dominates the headlines. For example, one headline was captioned "Christ Apostolic Church President Docked for Forgery". 48 The comments made recently by Pastor Akinosun in an interview, regarding the series of lawsuits in the church, are very apt:

The only remaining matter in court now is the so-called appeal against the judgment we obtained at the Federal High Court in Lagos. The persons who sued the registered trustees and the General Executive Council of the church had appealed against the judgment of the Federal High Court, Lagos, which adjudged the General Executive Council as the only authentic authority of the church. The criminal case, which they had hyped and which they were pursuing with zeal at the Federal High Court, Ibadan against some of our leaders, was decided recently. The criminal case was prosecuted by the Federal Government following a petition they wrote. The case had been into various courts since 2000 ... The remaining appeal at the Court of Appeal in Lagos was initiated by the people who were originally sued and against whom the judgment was given. Unfortunately, those who took the case to the appeal court are now dead. Our brothers on the other side are trying to ask the court of appeal to substitute the dead litigant for a new set of people with whom the church had no dispute so that those people can continue with the case ... The activities of some of these so-called independent CAC planters are very embarrassing. We cannot continue to watch them soiling the image of the church. ${ }^{49}$

Similar to the situation in the CCC, as recounted by Olusegun Alokan, a Nigerian scholar of religious studies, the leadership crises in CAC resulted in physical violence to the extent that many church leaders died in the struggle and church buildings shut their doors. ${ }^{50}$ Corroborating this account, Peter Awojobi, a Nigerian cleric and professor of theology, narrated an event in one of the branches of the church in December 2012:

In another development, as Christians worldwide were celebrating Christmas and giving glory to God for bringing them to the end of 2012, worshippers, at the Christ Apostolic Church in a branch in Lagos were busy waging a battle of supremacy and allegiance. The crisis in the church which has been ongoing for more than 20 years took a dangerous turn when two factions of the church clashed during a Sunday morning service. It was gathered that the Lagos based faction which was busy with church activities was suddenly brought to an end when the Ibadan based faction

48 Jegede J. 2011. "Christ Apostolic Church President Docked for Forgery", All Africa, 29 September; For a similar report regarding dispute in the Assemblies of God Church, see Adebowale S. 2016. "Forgery: Police Forward Assemblies of God's General Superintendent's Case File to Director of Public Prosecution (DPP)", The Eagle Online, 12 September.

49 Akinosun A. 2017. Interview, Nigerian Tribune (Ibadan), 26 May (emphasis added).

50 Alokan OAP, Alabi DO and Babalola SF. 2011. "Critical Analyses of Church Politics and Crises within the Indigenous Christianity in Nigeria", American Journal of Social and Management Sciences 2(4):364-365. 
arrived and chased them away. The aggrieved faction disconnected the electricity supply to the church after they were chased out, leaving the Ibadan faction to conduct their service without electricity supply. ${ }^{51}$

Given the above, it is not gainsaying that these series of disputes would have had devastating effects on the churches and church members.

\section{EFFECTS OF CHURCH DISPUTES ON HUMAN FLOURISHING}

The relevant question at this point is, what correlation exists between church leadership disputes and churches' roles in the promotion of citizens' well-being? In other words, does the increase in church leadership disputes impact churches' external functions? In response to these questions, the writer submits hereunder that church disputes have implications for churches' sustainability in the promotion of human flourishing.

\section{Strife amongst members}

As observed earlier, happiness and peaceful coexistence are part of what makes humans flourish. A church should be a spiritual space where people feel happy and get satisfaction, a place where people serve God and fellowship joyfully in the community of other believers. However, tension is created where a church becomes divided and members resort to the use of "charms", physical violence, court injunctions, and the police to intimidate and harass one another as observed in the case examples. ${ }^{52}$ Where a church turns into a "dispute arena", the happiness, close social relationship, and satisfaction that is derived from religious activities members may be lost. For example, Ebenezer Oshoffa, one of the sons of the founder of the CCC, recently stated in an interview that there is already a vacuum in the church. ${ }^{33}$ Similarly, the bitterness that disputes bring to a church may make some members withdraw from attending church activities. Justice Ogundare noted this in Owodunni when he observed some members of the CCC were "dispirited". However, researchers like Marc Musick, a professor of medical sociology and Tyler VanderWeele, a professor of public health, have noted that it is attending religious services and fellowship, rather than private practices or self-assessed religiosity that is most strongly predictive of human well-being. ${ }^{54}$

51 Awojobi, "Leadership Conflict in the Nigerian Church", 4.

52 In Registered Trustees, Holy Apostolic Church $v$ Ayeni and Another (2008) FWLR (Pt. 115) 708, the court was moved to make an order to lock up a church building because of leadership crises; See also Nwachukwu JO. 2018. “Drama as Foursquare Gospel Church, Ex-Pastor Contest Church Ownership, Members Locked Out by Police", Daily Post, 11 February. It was reported here that in the leadership crisis in the Foursquare Gospel Church, Nigeria, a leadership faction obtained an injunction and used armed police to seal up a branch of the church in Lagos.

Oshoffa E. 2015. Interview, Church Times (Ota), 21 December.

54

Musick "Attendance at Religious Services and Mortality in a National Sample", 198-213; VanderWeele TJ et al. 2017. "Attendance at Religious Services, Prayer, Religious Coping, 


\section{Loss of reputation}

An empirical study in 2014 by the World Values Survey confirms that religious organisations and their leaders have more influence on Nigerians than the political institutions do. ${ }^{55}$ Thus, through this influence and their prophetic mission, churches are expected to influence government policies that will promote social justice and equity. The citizens look up to churches as independent voices to speak with authority and condemn social vices associated with falling values and erring economy, such as bribery, corruption and policies that are perceived to be repressive and exploitative. However, many churches are losing their integrity as the news of their legal controversies is made public. Pastor Akinosun of the CAC admitted this in his interview when he lamented that his faction "cannot continue to watch them ... soiling the image of the church". The credibility of some churches is compromised, because they not only resort to the law courts, but also consult influential politicians to resolve their internal disputes. For instance, the leaders of CCC reportedly consulted Olusegun Obasanjo, a politician and former Nigerian president, to play a peacemaker in the CCC leadership tussle. ${ }^{56}$ Little wonder the same Olusegun Obasanjo allegedly demeaned the Christian Association of Nigeria ${ }^{57}$ and likened this ecumenical body to his "foot" ${ }^{58}$ Where a dispute involving forgery or financial mismanagement by church leaders tops the headlines, the question is, what moral justification or courage would such a church have to condemn social vices in the society? The point is, humanity cannot be said to be flourishing when social vices, injustices and inhumane policies thrive, and churches in their prophetic role cannot condemn them.

\section{Loss of focus and progress}

It is trite that where there is strife, progress is absent. As the saying goes, "a house that is divided against itself cannot stand". A legal dispute is an obstacle to the progress and development of any church. It blurs its vision and destroys its unity.

and Religious-Spiritual Identity as Predictors of All-Cause Mortality in the Black Women's Health Study", American Journal Epidemiology 185:515-522.

55 The study reveals that religious organisations influence 97 percent of Nigerians, whereas only 39 percent regarded political institutions as important. See World Values Survey. 2014. “World Values Survey Wave 6: 2010-2014". Online at: http://www.worldvaluessurvey.org/ WVSOnline.jsp; See also United States Commission on International Religious Freedom (USCIRF). 2018. Annual Report, 53; Akinloye IA. 2018. “Towards the Implementation of Sustainable Development Goals in Nigeria: Maximising the Influence of Religious Leaders", Stellenbosch Theological Journal 4(1):47-51.

56 Adeseri, "Celestial Church Leadership Crisis: Obasanjo Plays Peace Maker".

57 The Christian Association of Nigeria was founded in 1976. It is the largest Christian ecumenical body established to be the powerful Christian voice in Nigeria.

Magaji B. 2014. “President Obasanjo's Gratuitous Insult on Christians". Online at: http:// www.gamji.com/article3000/NEWS3555.htm; Obateru T and Mamah E. 2004. “Obasanjo Spits Fire, Calls CAN Boss 'Idiot'”, Vanguard, 14 May. 
A church in dispute must strive not to lose its members, image and integrity. Also, the parties to the dispute would win only after a hard-fought battle against the opponents who are likely fellow believers and church members. Accordingly, the promotion of human flourishing will no longer be the focus of such a church, but at best, the flourishing of some members over others. Examples can be drawn from the Assemblies of God Church, Nigeria, which owns Evangel University in Akaeze, Ebonyi State. The leadership succession lawsuit that rocked the church recently led to the disruption in the progress of the university when the suspended General Superintendent of the church, Rev Paul Emeka, was alleged to have singlehandedly and without consulting any member of the church council, suspended the principal officers of the university. ${ }^{59} \mathrm{He}$ also, reportedly, advertised their positions and dissolved the governing council of the university. ${ }^{60}$

\section{Waste of resources}

It is a fact that huge costs are expended to prosecute a lawsuit. ${ }^{61}$ Therefore, one wonders at the huge resources the CCC and CAC must have dissipated on the multiple lawsuits they pursued over the last three decades. Since lawsuits expose churches to great financial expenses, the resources that might have been used for the achievement of laudable goals and providing social services for which some churches are known were instead utilised in pursuing the course of litigation. If these resources were awarded as scholarships to indigent students, it might have helped them fulfil their lives' dreams; if invested in medical care, it might have saved lives. Akin to the above is the fact that church disputes promote non-accountability and enhance corruption. ${ }^{62}$ For example, one of the issues the Supreme Court had to resolve in the CCC in Owodunni is accountability and management of church property, because each faction took possession and management of some of the church property without accountability to each other. ${ }^{63}$ In Godwin v Christ Apostolic Church, ${ }^{64}$ another suit involving a leadership conflict in CAC, the church had to pray the court to compel the respondent, a church leader, to render account of

59 Rev. Paul Emeka v Rev. Chidi Okoroafor and Others (2017) LPELR-41738(SC).

60 Alaje V. 2014 "Emeka is Tearing Assemblies of God Apart with His Autocracy", Nigeria Nation, 5 July.

61 For instance, in Ebhodaghe v Deeper Life Christian Life Ministry [2016] LPELR 40582 CA, the sum of 5,000,000 Nigerian naira (equivalent of $\$ 30,000$ at the time of the judgment) general damages was awarded against the Deeper Life Christian Life Ministry. The same amount was awarded against the Assemblies of God Church in Rev Nicholas Anyanwu v Rev. Chidi Okoroafor and Others for unlawfully dismissing the claimant as a church leader.

Mbamalu WO. 2016. "Fellowship at Orita: A Critical Analysis of the Leadership Crisis in the Assemblies of God, Nigeria", Die Skriflig 50(1):6. The author narrated how a leadership faction in Assemblies of God Church alleged Rev Paul Emeka, who leads another leadership faction, of corruption and mismanagement of church funds. 
the church property and money in his possession. Accordingly, Sola Aworinde, ${ }^{65}$ a Baptist cleric, rightly observes that, "when there is conflict in the church, there will be unnecessary and careless spending; lack of transparency and misappropriation of funds will be the order of the day." 66 This may ultimately have implication for the flourishing and sustainability of churches.

\section{Schism and burden of members}

A lawsuit may polarise a church and result in schisms. Scholars such as Christopher Oshun and Ezekiel Adeoti, the latter a social history scholar, describe how no fewer than ten churches broke away from CAC because of leadership disputes. ${ }^{67}$ Polarisation may further lead to a legal dispute to determine how the properties of a church that is experiencing schism are to be divided amongst the factions. Even though most churches rarely contemplate schisms and divisions of church property in their internal orders, the lawsuits that may arise from the division of church property can hardly be escaped. Polarisation poses a burden on the members of the seceding faction, who must then start a new church from scratch. This, in itself, is averse to the well-being of the members, because the resources that might have been used to promote human flourishing must now be used to acquire new properties for the new church. Equally, the church from which a new church has emerged will also experience reduced income which becomes a limitation on the promotion of human flourishing activities.

It is pertinent to note at this point that several factors may lead to leadership conflicts in a church that ends up in civil courts. According to Awojobi, such factors include doctrinal differences, racial discrimination, incompetence, lack or poor succession planning, greed, power conflict, personality clash and poor communication. ${ }^{68}$ However, an examination of most of these disputes suggests that missing governance appears to be the prevalent cause. For example, the root of the numerous lawsuits in the CCC was the vacuum in the church's internal order to provide for an effective leadership succession plan. Oshun and Adeoti also identify

65 Aworinde S. 1993. The Church in Crisis. Ibadan, Nigerian Baptist Convention Publication Department, 27.

66 In the Foursquare Gospel Church leadership dispute noted earlier, a church member reportedly described the leadership faction that obtained an injunction to seal up a church and arrest a pastor as "wicked and corrupt leaders". She retorted: "They should first of all give an account of the whole money they are collecting from different districts of the church before coming to ask for the account of this church. These people all fly first class seats to USA and other countries and their children are all studying abroad ... Go to our camp, it is nothing to write home about and nothing to be compared with other churches' camps despite the volume of money that is collected in the church. See Nwachukwu, "Drama as Foursquare Gospel Church, Ex-Pastor Contest Church Ownership, Members Locked Out by Police".

67 Oshun, "Proliferation of Churches in Nigeria: A Consideration of the Christ Apostolic Church", 13-14; Adeoti, "Origin, Nature and Trajectory of the Leadership Tussle in the Christ Apostolic Church, Nigeria: 1989-2010", 24.

68 Awojobi PO, "Leadership Conflict in the Nigerian Church". 
weak internal mechanisms, particularly poor management of church growth and weak disciplinary measures, as some of the factors that led to the CAC disputes. ${ }^{69}$ A theology scholar, Williams Mbamalu, also pinpoints internal constitutional governance vacuums as the major cause of the seemingly interminable disputes in the Assemblies of God Church, Nigeria. ${ }^{70}$ The increase in church disputes, their implications for the promotion of human flourishing and the fact that most of the disputes are arising from the lapses in the governance mechanisms of churches all make it imperative for churches to improve on the quality of their governance mechanisms to prevent and reduce their exposure to likely disputes.

\section{TOWARDS EFFECTIVE INTERNAL GOVERNANCE MECHANISMS}

To some extent, most churches, whether statutorily registered or not, do have structures and mechanisms of governance. For instance, Section 591 of the Companies and Allied Matters Act (CAMA), ${ }^{71}$ stipulates that a church that is desirous of registering its trustees must submit its constitution alongside other documents to the Corporate Affairs Commission (the Commission).$^{72}$ Section 593 of CAMA stipulates the minimum content such a constitution must have. For convenience, the Commission has now provided a model constitution, which most churches adopt as a template for registering their trustees. ${ }^{73}$ An observation that can be made at a glance is that the statutorily required contents of the constitution and the Commission's model constitution are too limited to address the contemporary risks and legal intricacies facing the churches. It is suggested that, beyond what is provided for in CAMA and the model constitution, churches need to develop for themselves, detailed and comprehensive internal policies for each of the major areas of their governance, particularly the areas that have been the bases of frequent legal controversies in recent times. Such policies should further include a general risk management strategy for the church. It is submitted that there is nothing sinister about churches seeking guidance from risk management practices that business entities use and adapt the same to suit their purposes and polity in order to reduce their exposure to risks of legal disputes. Furthermore, these policies must be reviewed regularly to meet contemporary legal intricacies facing the churches. ${ }^{74}$

69 Adeoti, "Origin, Nature and Trajectory of the Leadership Tussle in the Christ Apostolic Church, Nigeria: 1989-2010", 24-26; Oshun, "Proliferation of Churches in Nigeria: A Consideration of the Christ Apostolic Church", 17-21.

70 Mbamalu, "Fellowship at Orita", 6-7.

71 Companies and Allied Matters Act 1 of 1990, Chapter C20, Laws of the Federation of Nigeria, 2004.

72 The Commission is empowered under the provision of CAMA to register companies and non-profit organisations.

73 See the CAC's model constitution. Online at: http://new.cac.gov.ng/home/wp-content/ uploads/2013/11/MODEL_CONSITUTION.pdf

74 Van Coller H. 2001. "Church Polity and 'Constitutionalism'”, in Koffeman LJ and Smit J (eds). Protestant Church Polity in Changing Contexts II. Zurich: Lit Verlag, 147. Van Coller, a South African professor of law, observes: “Changing social, political and constitutional 
Moreover, appropriate choice of words must be used in the rules and policies. Inyang Ekwo, a theologian and a judge on the High Court in Nigeria, rightly observes that the words used in church mechanisms are the key to unlocking the intention of the church. ${ }^{75}$

As part of the risk management policy, churches should also make sure they have at least one practising legal practitioner as a member of the church governing bodies and trustees. An advisory legal unit can also be established. Such lawyers would advise churches on some issues that might expose them to disputes. This position is not only reasonable in the context of the increased church disputes, but is supported in the Bible. In his concluding remarks in his letter to Titus in the New Testament of the Bible, Paul instructs: "Do everything you can to help Zenas the lawyer" and Apollos on their way and see that they have everything they need. Our people must learn to devote themselves to doing what is good, in order to provide for urgent needs and not live unproductive lives." 77 Faraday Iwuchukwu, a Nigerian cleric and legal practitioner, exegeting that passage, posits:

The role of the Zenases in the in Church, to my own understanding, refers to the church's need for counselling that is legally and scripturally based emanating from legally trained minds, such as Christians lawyers. Such Christian lawyers are to offer free or paid professional legal services and counselling to both the laity and clergy in the churches for purposes of enlightenment, stability and steady healthy growth of the church. ${ }^{78}$

However, there is need for caution in adopting the above suggestion, because lawyers are essentially trained to end up in court. They might, accordingly, have a tendency to advise a church to take the litigation route in times of crisis. This concern was observed by Judge Goosen in the South African case of The Presbyterian Church of Africa $v$ Sihawu, ${ }^{79}$ in which Goosen stated:

One would hope however that an appeal to the rationality of the protagonists to this dispute and those legal practitioners who represent them, would cause them to seek a solution other than episodic litigation which appears to serve little purpose other than to entrench the enmity and to provide fuel for still more conflict within the Presbyterian Church of Africa.

contexts also place a duty on churches to adapt their structures and church orders in the light of constitutional demands." See also Chaskalson CJ in the South African case of Van Rooyen and Others $v$ S [2000]8 BCLR 810.

Ekwo IE. 2007. Incorporated Trustees: Law and Practice in Nigeria. Durban: LexisNexis, 74; Egbubson and Others v Joseph Ikechiuku (1977) All NLR 194.

76 Emphasis added.

77 Holy Bible. New International Version. Titus 3:13-14.

Iwuchukwu FON. 2013. "Legal Counsel for the Church: The Role of the 'Zenases' in the Church", The Scribe: Journal of Law, Faith and Ethics, 59.

Unreported, Case No: 3375/12, 13-14, para 29. 
In cognisance of these realities, it is necessary to clarify that the role of church lawyers is to provide counsel to forestall litigation or seek amicable and alternative measures to litigation in resolving internal church disputes. This is in keeping with Jesus's directive in Matthew 18:15-18 and Paul's directive in 1 Corinthians 6:1-6 that Christians should settle their disputes internally as against taking their disputes to the law courts.

Furthermore, the time is ripe for clergy and church leaders to seek basic training in church law. In order to achieve this, it is necessary for theological and higher institutions in Nigeria to devise curriculum and scholarship in the area of church law. While church leaders do not have to be experts on every legal issue that comes before them, they should, at least, be aware of the legal framework of their ministry. Presently, there is little or no literature in this field of law in Nigeria. As Inyang Ekwo has put it, "Notwithstanding the great age of the established church in Nigeria, this area of the law pertaining to the government of the church is as yet relatively underdeveloped, and there are many issues that are recondite. This is reflected in the dearth of historically established legal literature and reference material available, in inverse proportion to the number of living legal practitioners" 80

In addition to the above, the Christian Association of Nigeria (CAN) and its associate ecumenical bodies should establish an Ecclesiastical Law Society of Nigeria, analogous to the Canon Law Society of America, and charge this body with the mandate to continue to develop, examine, consider and identify current and potential legal issues affecting church governance and administration. The activities and reports of such a body might even foster review of each church's order as new issues emerge that affect church governance. For instance, Thomas Brundage, a Catholic priest and Judicial Vicar in the United States, while giving the testimony of how the Canon Law Society of America reduced the level of church disputes going to the courts, states:

For more than 30 years the Canon Law Society of America has studied the role of Canon Law in the resolution of internal disputes that arise within the church. Various structures have been tested in several American dioceses, some with greater success than others ... The archdiocese now has successfully heard about 90 cases of administrative recourse without a single one of these cases subsequently being taken to the civil courts. More important than the money saved by not having to pay attorney and court fees, settlements, and penalties, is the fact that the archdiocese has established structures that raise the level of justice for members of our local church..$^{81}$

Furthermore, CAN might also establish a conflict resolution department to resolve church disputes through alternative dispute resolution instead of going to civil

80 Ekwo, Incorporated Trustees: Law and Practice in Nigeria, 12-13.

81 Brundage TT. 2001. “Resolving Disputes within the Church". Online at: https://www. americamagazine.org/issue/348/article/resolving-disputes-within-church 
court. ${ }^{82}$ In England, the position is that church courts, exercise jurisdiction over disciplinary and moral offences by the clergy and some ecclesiastical offences of the laity and certain other matters. In matters concerning conduct, however, there can be an appeal to the Judicial Committee of the Privy Council and in other matters, there may be an appeal to the Court of Ecclesiastical Cases Reserved. These church courts in England are not courts of common law, and the prerogative orders which operate as a valuable check on the abuse of power by other courts and tribunals do not apply to them..$^{83}$ Thus, if CAN were to set up a conflict resolution department, it might be a step towards having a system of church courts in Nigeria, which would be similar to the Sharia Courts that are now recognised in the Nigerian Constitution. ${ }^{84}$ This mechanism, if implemented, would not only save the resources of the churches, but also their reputation. For instance, the legal dispute between the Celestial Church of Church and Deeper Life Christian Church over a landed property, ${ }^{85}$ which resulted in the award of five million naira in damages against Deeper Life Christian Church, could possibly have been resolved in-house by CAN and not the court. Otherwise, the absence of risk structures in the church mechanisms as enumerated above will continue to prompt Christian disputants to take their disputes to the civil courts in ways that limit the promotion of human flourishing.

\section{CONCLUSION}

This chapter has explored the effects of church leadership disputes on Nigerians well-being. It has maintained that churches play a central role in the promotion of human flourishing in the country. For instance, churches play integrative and social cohesion amongst Nigerians and have helped some of them find happiness, meaning and purpose in life through provision of access to education, job, amongst others. The churches' developmental projects also contribute to the welfare of the populace. However, a number of Nigerian churches have been subject of legal disputes in recent years, particularly regarding their leadership. These disputes lead to strife and hatred amongst congregants. The resources that church waste on lawsuits further inhibit churches' contributions to the society. Most importantly, church disputes have the capacity of robbing churches the boldness to speak against social injustices and vices that inhibit human flourishing. Certainly, where churches face legal disputes, their capacity to stimulate communal good is negatively affected.

82 Ilo P. 2014 “Faith-Based Organisations and Conflict Resolution in Nigeria: The Case of the Christian Association of Nigeria (CAN)", Journal of Global Initiatives 9(2):106. "CAN does not have enough trained personnel and adequate capacity. It also does not have a definite presence in conflict resolution."

83 Keenan D. 1992. Smith and Keenan's English Law. Tenth Edition. London: Pitman Publishing, 15-16.

84 Constitution of the Federal Republic of Nigeria, 1999, secs 260 and 275, establishes Sharia Courts of Appeal with jurisdiction to adjudicate civil proceedings involving questions of Islamic personal law.

Ebhodaghe v Deeper Life Christian Life Ministry. 
In other words, the propensity of a church to focus on activities that make citizen flourish is proportional to the peace it enjoys internally.

Amongst the various factors that can result in church leadership crises, absence of governance in providing for effective legal risk policies to shield churches from likely disputes appears to be the commonest. Therefore, it behoves churches to ensure to develop effective risk management policies in various aspects of their governance as a blueprint for reducing their exposure to legal disputes. Churches may not be absolutely immune from disputes, ${ }^{86}$ but having good, comprehensive, and workable internal procedures can help them to avoid the avoidable legal disputes that may need to be adjudicated by the civil courts and to mitigate the impacts of the unavoidable legal disputes. In the same vein, adopting some external risk management policies can also be of immense help to reduce churches' exposure to legal disputes and give room for them to further promote human flourishing.

86 Van der Schyff G. 2003. "Freedom of Religious Autonomy as an Element of the Right to Freedom of Religion", Journal of South African Law 528. 